\title{
Marek Czyżewski
}

\author{
Alicja Rokuszewska-Pawelek
}

\section{Komentarz do artykułu Analiza autobiografii Rudolfa Hössa}

Autobiografia Hössa jest wyjątkowo dobitną ilustracją problemu ogólnego: jak sprawcy drastycznych przestępstw i zbrodni ustosunkowują się do swych czynów? Ale może dostarczyć także impulsu do ogólnej refleksji z zakresu historii i socjologii kultury. Poniższe uwagi dotyczą obu wspomnianych kwestii.

A zatem, w jaki sposób sprawcy wypowiadają się na temat swych zbrodni? Rzecz jasna, wypowiedzi te można rozpatrywać z różnych punktów widzenia. Np. w perspektywie prawnej ważne jest to, czy sprawca przyznaje się do popełnionych czynów czy nie. Z moralnego punktu widzenia istotne jest natomiast, czy sprawca wyraża skruchę czy, przeciwnie, chełpi się swym okrucieństwem. W bliskim nam polu zainteresowania socjologii interpretatywnej oraz analizy dyskursu i retoryki znajdowały się przede wszystkim komunikacyjne techniki, za pomocą których sprawcy komentują swoje czyny. Tak właśnie ukierunkowana była nasza analiza autobiografii Hössa. W toku pracy uwagę naszą zwrócił szczególny aspekt analizowanego materiału: kontrast między monstrualnością zbrodni Hössa i ,zwyczajnym” charakterem jego wypowiedzi. Można powiedzieć, że lektura autobiografii Hössa poruszyła nas nie tylko z uwagi na ogrom zła, o którym traktuje, lecz także, a może przede wszystkim, z uwagi na zdystansowany, zdroworozsądkowy, a po części niemal analityczny sposób relacjonowania i komentowania zła. Przeciwstawny tryb relacji, polegający na popadnięciu w ton emfazy, byłby, co warto podkreślić, równie problematyczny. Jednak znaczący brak (lub nieumiejętność) zmierzenia się z absolutnym złem, którego było się samemu aktywnym narzędziem, zdumiewał i szokował. Lektura autobiografii Hössa, jak również wypowiedzi innych zbrodniarzy prowadzić może do wniosku, że milczenie byłoby niejednokrotnie rozwiązaniem lepszym. Sprawcy kompromitując się swymi zbrodniami kompromitują się bowiem ponownie wtedy, gdy mówią o nich w niestosowny, nieadekwatny czy oburzający sposób.

Dzisiaj, po niemal trzydziestu latach, nasuwa się pytanie o aktualność naszej analizy. Oczywisty wydaje się jej historyczny walor, lecz nasze ustalenia mogą, jak się zdaje, służyć ponadto jako materiał porównawczy w ramach analizy wypowiedzi sprawców innych zbrodni. Ryzykując krok w stronę szerszej problematyki historii i socjologii kultury można byłoby radykalnie powiększyć pole 
zainteresowania tak, by objęło ono nie tylko sposoby mierzenia się ze złem absolutnym, lecz także sposoby ustosunkowywania się do fenomenów pod wieloma względami całkowicie odmiennych (takich jak kontakt z arcydziełami sztuki czy skrajne doświadczenia egzystencjalne), które jednak - oczywiście na całkowicie odmiennej drodze - również przekraczają horyzont życia codziennego. W naukach społecznych od lat rozpatrywana jest hipoteza, zgodnie z którą cechą współczesnej cywilizacji w coraz większym stopniu miałaby być pragmatyzacja świadomości i masowe znieczulenie na wszystko to, czego nie da się objąć praktycznymi objaśnieniami. Na tej drodze cywilizacja współczesna ma sama sobie odmawiać dostępu do sfery tajemnic, których nie sposób poddać kontroli za pomocą zdroworozsądkowych wskazówek lub sprofesjonalizowanych porad ani przetworzyć w konsumpcyjny produkt kultury popularnej. Rudolf Höss może i powinien nadal szokować swym „znieczulonym” podejściem do tego, się działo w Auschwitz. Znacznie trudniej byłoby pogodzić się nam z dalej idącym przypuszczeniem, iż, mimo wszelkich doniosłych różnic, w pewnym stopniu analogiczne znieczulenie na transcendencję może mieć miejsce np. w redukcjonistycznych (socjologicznych bądź psychologicznych) interpretacjach dzieł sztuki, czy w ramach powszechnej psychologizacji i terapeutyzacji problematyki egzystencjalnej.

Praktyki normalizacyjne stosowane przez Hössa słusznie nas nadal oburzają. Podobne praktyki podejmowane przez sprawców innych zbrodni też nas oburzać powinny. Być może jednak spektakularny charakter zbrodni oraz oczywisty, wręcz nieprzyzwoity kontrast między zbrodnią i jej komunikacyjną normalizacją utrudniają nam szerszy ogląd sytuacji. Być może nie dostrzegamy szerszego procesu normalizacji, który dzieje się przed naszymi oczami i który polega na tym, że rozmaite sektory rzeczywistości wykraczające poza horyzont doświadczenia codziennego są systematycznie do niego redukowane. Na tej drodze autobiografia Hössa mogłaby być potraktowana jako tzw. materiał transgresywny, który poprzez swoją skrajność dostarcza wglądu w niedostrzegane, szersze zjawiska.

Trzeba wreszcie podkreślić, że praktyki normalizacyjne stosowane są także przez ofiary przemocy i prześladowania, o czym świadczą m.in. wspomnienia więźniów obozów koncentracyjnych, jak również ich literackie przetworzenia, np. w postaci opowiadań Tadeusza Borowskiego czy powieści Los utracony Imre Kertésza. Wówczas jednak komunikacyjna funkcja normalizacji jest całkowicie odmienna. O ile bowiem normalizacja praktykowana przez sprawców służy rozmyciu odpowiedzialności za zbrodnię, o tyle ofiary, normalizując swoje drastyczne doświadczenia, podejmują desperacką próbę poradzenia sobie z traumą, natomiast literacka normalizacja rzeczywistości obozowej stanowi paradoksalny sygnał braku języka, za pomocą którego można byłoby o tej rzeczywistości mówić. 